\title{
PENDEKATAN ANN (ARTIFICIAL NEURAL NETWORK) UNTUK PENENTUAN PROSENTASE BOBOT PEKERJAAN DAN ESTIMASI NILAI PEKERJAAN STRUKTUR PADA RUMAH SAKIT PRATAMA
}

\author{
Aulia Yudha Prathama, Akhmad Aminullah, dan Ashar Saputra \\ Departemen Teknik Sipil dan Lingkungan, Universitas Gadjah Mada \\ Email: aulia.yudha.prathama@mail.ugm.ac.id
}

\begin{abstract}
Cost estimation in the process of building design has an important role. Therefore the need for estimation tools from both the planning and project management aspects needs to be developed. This paper discusses the benefits of Artificial Neural Network methodology to overcome the problem of cost estimation of the value of structural work at the stage of building design process. The value of the structural work itself has a considerable allocation of the total contract and is an important work item in a building construction project. The related data to the value of structural work and the design of work items from 8 projects used for training and testing Artificial Neural Network (ANN) method with seven design variables used in estimating the cost value of structural work from Pratama Hospital building in remote areas in Indonesia, We obtained the best empirical equations from ANN simulation for hospital cost estimate building contract at the planning stage with the best ANN structure 7-9-1 (7 input variables, 1 hidden layer with 9 neurons and 1 output) with the result of an average cost estimation $96.51 \%$ achieved.
\end{abstract}

Keywords: Artificial Neural Network; Building design; Cost estimation; Hospital; The value of structural project.

\begin{abstract}
ABSTRAK
Pengambilan keputusan dalam estimasi biaya dalam proses perancangan bangunan memiliki peranan penting. Oleh sebab itu kebutuhan akan alat estimasi baik dari sisi desain perencanaan maupun manajemen proyek perlu dikembangkan. Makalah ini membahas manfaat metodologi jaringan syaraf tiruan (Artificial Neural Network) untuk mengatasi masalah estimasi biaya nilai pekerjaan struktural pada tahap proses perancangan bangunan. Nilai pekerjaan struktural sendiri memiliki alokasi yang cukup besar dari total kontrak dan merupakan item pekerjaan yang cukup penting dalam suatu pekerjaan konstruksi bangunan. Data terkait nilai pekerjaan struktural dan desain item pekerjaan dari 8 proyek digunakan untuk pelatihan dan pengujian Metode Artificial Neural Network (ANN) dengan tujuh variabel desain digunakan dalam memprakirakan nilai biaya pekerjaan struktural dari bangunan Rumah Sakit Pratama pada daerah terpencil di Indonesia. Dari simulasi ANN diperoleh persamaan empiris terbaik untuk prakiraan harga kontrak gedung rumah sakit pada tahap perencanaan dengan struktur ANN terbaik 7-9-1 (7 variabel input, 1 hidden layer dengan 9 neuron dan 1 output) dengan hasil akurasi estimasi biaya rata - rata $96.51 \%$ tercapai.
\end{abstract}

Kata Kunci: Artificial Neural Network; Desain bangunan; Nilai pekerjaan struktural; Prakiraan biaya; Rumah sakit. 


\section{PENGANTAR}

Gedung Rumah Sakit merupakan salah satu kontruksi gedung Negara yang termasuk dalam kategori bangunan tidak sederhana. Adanya kebijakan pemerintah terkait otonomi daerah menyebabkan diperlukan pemerataan segala bidang terkait pembangunan termasuk kesetaraan pelayanan kesehatan. Terlebih pemerintah mengalokasikan dana APBN sebesar 5\% (lebih dari 100 Triliun Rupiah) dalam sektor kesehatan. Salah satu dari alokasi dana tersebut digunakan untuk pembangunan Rumah Sakit Pratama yang digunakan untuk memfasilitasi dan membantu pelayanan kesehatan terutama di daerah wilayah terpencil di Indonesia agar kegiatan pelayanan dan kesehatan masyarakat semakin meningkat dan merata.

Prakiraan biaya pada umumnya diperlukan pada tahap persiapan dari suatu proyek yang diperinci lebih lanjut menjadi tahap konseptual dan tahap perencanaan dan pemantapan. Biaya merupakan salah satu kriteria utama dalam pengambilan keputusan pada tahap awal saat proses perancangan desain bangunan. Di dunia konstruksi yang sangat kompetitif saat ini, mengurangi margin dari keuntungan dan penurunan harga pada pangsa pasar, dan pengendalian biaya memainkan peran penting untuk menjadikan biaya lebih efisien sambil mempertahankan tingkat mutu kualitas yang baik. Nilai biaya bangunan dipengaruhi secara signifikan oleh keputusan yang dibuat pada tahap perancangan konstruksi. Meningkatnya biaya konstruksi membuat keputusan yang efektif dan efisien sehingga membuat prakiraan biaya menjadi aspek penting dalam mendesain konstruksi. Desain dari pekerjaan struktural sangat penting untuk mempengaruhi total biaya suatu konstruksi. Pada sampel nilai pekerjaan struktur sendiri memiliki alokasi yang cukup besar, dari total kontrak berkisar $33.05-46.69 \%$ dan merupakan salah satu paket pekerjaan yang cukup penting dalam suatu pekerjaan konstruksi bangunan. Tujuan penelitian ini adalah perancangan menggunakan teknik estimasi biaya dan penilaian intuitif dengan memanfaatkan pengalaman dan data pembangunan Rumah Sakit Pratama dari proyek-proyek sebelumnya. Perkembangan teknologi komputer dan perangkat lunak telah memberikan manfaat pendekatan baru untuk estimasi biaya. Dengan munculnya alat Artificial Intelligence (AI) (yaitu, jaringan syaraf tiruan) dalam hal memprediksi kemungkinan hubungan multi-dan non-linear yang mempengaruhi estimasi biaya pekerjaan struktural agar dapat diselidiki (Dogan, 2004).

Realita di lapangan menunjukkan bahwa desain bangunan dan material yang dipilih memiliki efek signifikan terhadap biaya bangunan. Biaya bangunan terdiri dari beberapa barang termasuk sistem struktur, pekerjaan dinding, pintu dan jendela, sistem mechanical dan electrical, arsitek, dan lain-lain. Bobot relatif dari pekerjaan ini berbeda untuk berbagai proyek sesuai dengan jenis dan penggunaan bangunan.

Untuk tipe bangunan bertingkat menggunakan struktur beton bertulang, sistem kerangka struktural termasuk fondasi mencakup sekitar 25\% dari total biaya konstruksi. Biaya keseluruhan bangunan dapat menurun cukup jauh jika sistem struktur dirancang secara efisien. Oleh karena itu, baik arsitek maupun insinyur struktural harus berhati-hati dalam membuat keputusan desain untuk sistem struktur.

Tujuan dari penulisan ini adalah untuk mengembangkan dan menguji model dan variabel yang berpengaruh pada estimasi biaya untuk sistem struktur bangunan beton bertulang pada tahap perancangan awal melalui penerapan metode Artificial Neural Network. Model ANN dapat membantu perencana membuat keputusan berdasarkan keputusan awal pada proses perancangan. Dengan metode ini diharapkan mungkin dapat memprediksi dan menghasilkan rumus estimasi cukup akurat, walaupun informasi yang memadai tidak tersedia ditahap awal proses perancangan. Pendekatan ini 
mendorong proses umpan balik yang dapat membantu perencana untuk mencapai solusi optimal.

Data sampel yang digunakan untuk estimasi biaya dalam makalah ini berasal dari laporan penelitian analisis biaya konstruksi Rumah Sakit Pratama pada Kementerian Kesehatan tahun 2015. Sebagai negara berkembang, Indonesia dikatakan sedang mengalami pertumbuhan populasi yang cepat dan sejajar, dengan ini pelayanan kesehatan bagi rakyat harus dicukupi pemerintah sampai sektor daerah.

Pembangunan Rumah Sakit Pratama mempunyai tujuan memfasilitasi dan membantu pelayanan kesehatan terutama di daerah wilayah terpencil di Indonesia agar pelayanan dan kesehatan masyarakat semakin meningkat dan merata. Dengan pertimbangan ini, terkait biaya pekerjaan struktural yang mempengaruhi hasil bangunan konstruksi menjadi isu yang semakin penting di negara-negara berkembang seperti Indonesia. Minimnya data, keterbatasan waktu, dan kekurangan sumber daya yang paham mengenai perhitungan prakiraaan harga pekerjaan struktural merupakan masalah utama. Oleh karena itu perlu dilakukan juga peninjauan pada faktor-faktor yang memliki korelasi erat terhadap biaya pekerjaan struktural pembangunan gedung Rumah Sakit Pratama selain faktor jarak lokasi proyek dan IKK (Indeks Kemahalan Konstruksi) yang khususnya tersedia pada tahap persiapan, sehingga dapat tercipta suatu metode perhitungan prakiraan biaya menggunakan metode ANN yang lebih akurat.

\section{Metode}

Untuk mencapai tujuan penelitian di atas, sebuah metodologi penelitian dua langkah perlu dikembangkan. Pada tahap pertama, model estimasi nilai biaya berbasis ANN pada penelitian sebelumnya dipelajari dan diselidiki. Pada tahap kedua, model ANN dirancang untuk estimasi nilai biaya pekerjaan struktural dalam tahap perancangan pembangunan Rumah Sakit Pratama. Kemudian model diuji untuk mendapatkan konfigurasi jaringan arsitektur model terbaik. Pemodelan untuk tahap training menggunakan delapan data pada proyek nomer 2, 4, 5, 6, 7, 10, 11, dan 12 . Untuk pengujian data validasi hasil dari tahap training, menggunakan empat data lain di luar training set pada proyek nomer 1, 3, 8, dan 9 . Tahapan terkait metodologi akan dipaparkan pada bagian berikut.

\section{Aplikasi ANN dalam Estimasi Biaya Pekerjaan Struktural}

Inspirasi untuk model Artificial Neural Network berasal dari studi proses di otak manusia. Jaringan-jaringan tersebut memperoleh pengetahuan melalui proses pembelajaran. Dalam hal ini koneksi antar-neuron yang dikenal sebagai bobot sinaptik digunakan untuk mengingat pengetahuan (Kusumadewi, 2004). Kemampuan belajar jaringan saraf ini memberi keuntungan dalam memecahkan masalah kompleks yang solusi analitik dan numeriknya sulit didapat. Estimasi biaya pekerjaan struktural pada tahap perancangan awal adalah salah satunya masalah.

Beberapa peneliti telah menggunakan jaringan syaraf tiruan sebagai alat untuk prediksi dan optimasi sebelumnya, tetapi di bidang estimasi biaya hanya ada sedikit yang mengaplikasinya. Karya-karya Shtub dan Versano, terdiri dari model ANN alternatif untuk memperkirakan biaya. Shtub dan Versano telah mengembangkan sebuah sistem yang berbasis pada ANN yang dilatih untuk menafsirkan estimasi biaya ketika sebuah teknologi baru diperkenalkan untuk pipa baja. Mereka juga menemukan bahwa jaringan syaraf tiruan mengungguli regresi linier analisis untuk estimasi biaya. Zhang dan Fuh merancang model ANN untuk estimasi biaya awal produk kemasan. Dalam model mereka, mereka mengekstrak dan menghitung variabel sensitif biaya dari desain produk. Korelasi antara variabel komponen biaya dan biaya akhir produk ditemukan dengan menggunakan algoritma ANN berdasarkan data pekerjaan sebelumnya. 
Pada hasil studi Erlianingsih (2016), rumus empiris terbaik dari hasil permodelan Artificial Neural Network yang dapat digunakan memprakirakan biaya pembangunan gedung kampus pada tahap konseptual untuk prakiraan biaya dengan konfigurasi ANN 6-9-1 (6 (enam) variabel input), 1(satu) hidden layer dengan 9 (sembilan) neuron dan 1 (satu) output). Prosentase error / MMRE maksimal yang dihasilkan adalah sebesar $6.39 \%$. Sementara hasil penelitian Kesturi (2012) Estimasi Biaya Tahap Konseptual pada Konstruksi Gedung Perkantoran dengan Metode ANN, meneliti terkait penggunaan model arsitektur ANN untuk estimasi biaya pada gedung perkantoran memiliki nilai deviasi MMRE sebesar 7.79\% lebih baik dari kriteria deviasi tahap konseptual menurut AACE (American Association of Cost Engineering), yaitu, kelas 4: dengan range deviasi $-15 \%--30 \%$ dan $+25 \%-+50 \%$. Aptiyasa (2012), dalam penelitiannya tentang cost model estimasi konseptual bangunan gedung rumah sakit menghasilkan nilai akurasi model estimasi biaya pembangunan gedung rumah sakit dengan metode "Cost Significant Model" adalah berkisar antara rentang $-12.97 \%$ sampai dengan $+26.80 \%$, dengan rata-rata $+2.865 \%$.

Smith dan Mason, (1997) juga meneliti kinerja, stabilitas, dan kemungkinan pemodelan estimasi biaya menggunakan regresi versus ANN untuk mengembangkan hubungan dengan estimasi biaya. Mereka menjelaskan bahwa data biaya tidak memungkinkan untuk desain model yang umum dipilih. Masalah arsitek model menjadi lebih kompleks karena dimensi dari variabel independen berkembang. Kurangnya pengembangan model estimasi biaya menggunakan ANN untuk tahap desain perencanaan awal memotivasi penulis dan model ANN untuk ke depannya perlu dikembangkan.

\section{Perancangan Model Arsitektur ANN}

Permasalahan yang disajikan dalam makalah ini didasarkan pada optimalisasi desain dan prediksi dalam mengonfigurasi arsitektur jaringan syaraf tiruan umpan balik dan sistem teknik pembelajaran backpropagation.

Perangkat lunak MATLAB serta spreadsheet excel digunakan untuk pemodelan. Model telah dikembangkan dalam tiga tahap: fase pemodelan, fase pelatihan, dan tahap pengujian. Tahap pemodelan melibatkan analisis data, identifikasi variabel estimasi biaya dan pemilihan arsitektur jaringan. Tahap pelatihan memerlukan persiapan data dan penerapan alogaritma pembelajaran untuk pelatihan. Tahap pengujian mengevaluasi akurasi prediksi model ANN terkait biaya sebenarnya dibandingkan dengan perkiraan biaya ANN dan persentase kesalahan biaya kemudian dihitung.

\section{Tahap Pemodelan}

Tahap pemodelan, yaitu perancangan arsitektur ANN. Tahapan Ini merupakan proses yang kompleks dan dinamis yang memerlukan penentuan struktur permodelan dan aturan internal (yaitu, jumlah lapisan tersembunyi dan neuron dan jenis fungsi aktivasi). Model ini dirancang sesuai dengan jenis data dan respon yang dibutuhkan oleh aplikasi ANN (Gambar $1)$.

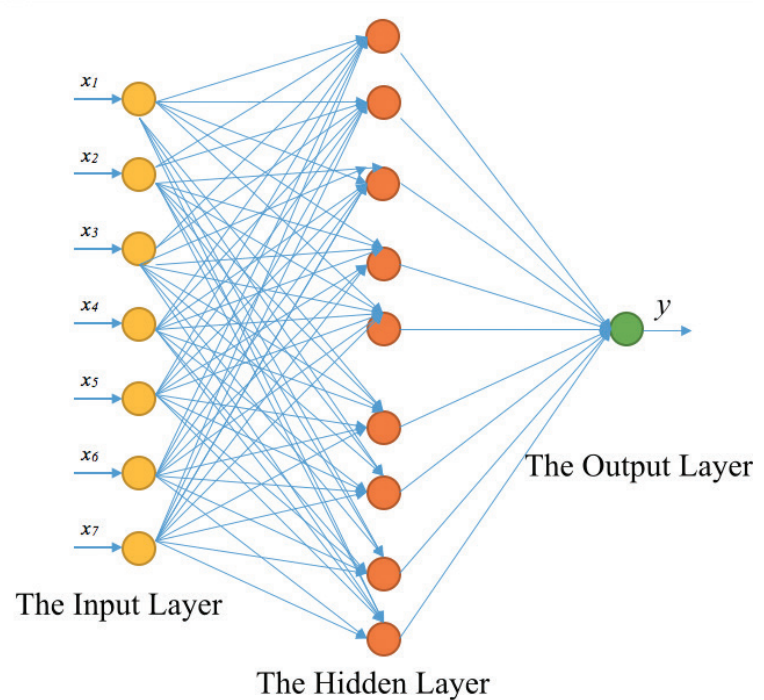

Gambar 1.

Model Arsitektur Neural Network 
Tabel 1. Desain Variabel Model ANN untuk Mencari Harga Pek. Struktur

\begin{tabular}{|c|c|c|}
\hline Variabel & Definisi & Range Data \\
\hline (1) & (2) & (3) \\
\hline$x_{1}$ & Luas Bangunan & $1194.69-2263.45 \mathrm{~m} 2$ \\
\hline$x_{2}$ & Bentang Kolom Rata-Rata & $3.43-4.96 \mathrm{~m}$ \\
\hline$x_{3}$ & Prosentase Pekerjaan Struktur Tanah dan Pondasi & $1.53-6.10 \%$ \\
\hline $\mathrm{x}_{4}$ & Prosentase Pekerjaan Beton dan Pelat Lantai & $15.07-26.43 \%$ \\
\hline$x_{5}$ & Prosentase Pekerjaan Struktur Atap & $11.29-16.10 \%$ \\
\hline$x_{6}$ & IKK & $77.59-219.74$ \\
\hline$x_{7}$ & Jarak Lokasi Proyek dengan Pusat Kota & $28-523 \mathrm{Km}$ \\
\hline $\mathrm{y}$ & Harga Pek. Struktur & Rp 2,170,388,545,00 - Rp 6,260,812,639,00 \\
\hline
\end{tabular}

Model ANN saat ini telah dirancang untuk memasukkan input layer dari tujuh elemen pemprosesan (neuron) yang sesuai dengan tujuh parameter input dan output layer dari satu elemen pemrosesan (neuron) sebagai target. Satu hidden layer dari sembilan elemen proses dipilih setelah beberapa percobaan selama tahap pengujian. Fungsi hidden layer adalah mengekstrak serta mengingat fitur yang berguna. Subfitur dari pola input kemudian digunakan untuk memprediksi hasil jaringan atau nilai lapisan output (Kusumadewi, 2004). Oleh karena itu, sejumlah elemen pemrosesan yang efektif biasanya ditentukan oleh uji coba untuk hidden layer, karena tidak ada aturan untuk menentukannya. Model ANN dibentuk secara empiris, bukan berasal dari teoritis. Parameter kunci (yaitu, variabel desain bangunan) untuk lapisan masukan dipilih dari analisis data eksperimental untuk mengevaluasi hasil output data (yaitu, biaya pekerjaan struktur) yang ditunjukkan pada Tabel 1. Model estimasi biaya didasarkan pada variabel desain berikut dan target output sesuai pada gambar. (Gambar 1).

\section{Analisis Data dan Identifikasi Variabel Desain}

Penyusunan model dilakukan dengan mengatur parameter yang telah disesuaikan untuk mendapatkan hasil waktu komputasi, error model dan error prediksi yang minimal (Wartati $d k k$., 2016). Parameter ini adalah pendorong biaya utama dari contoh kasus. Metode ANN mendefinisikan karakteristik formal bangunan dan jumlah bahan yang dibutuhkan untuk konstruksi struktural bangunan.
Nilai prosentase pekerjaan struktur tanah dan pondasi, perkerjaan beton dan pelat lantai, pekerjaan struktur atap terlebih dahulu kita cari besaran nilainya dengan pendekatan ANN. Ketiga varibel tersebut kita gunakan sebagai output data awal yang dicari sebagai variabel output ANN, dengan input varibel seperti: luas bangunan, koefisien gempa, kemiringan atap, bentuk bangunan, jumlah ruangan kamar rawat inap, jenis material atap, tinggi bangunan, jarak bentang kolom terpanjang, dan jarak bentang kolom ratarata, sehingga output awal ANN didapatlah nilai pada variabel $x_{3^{\prime}} x_{4^{\prime}}$ dan $x_{5}$ pada tabel 1. Jarak lokasi proyek dengan pusat ibukota provinsi serta nilai IKK diasumsikan memiliki pengaruh terhadap penambahan alokasi biaya pada item pekerjaan struktural. Nilai IKK menurut BPS (2015) digunakan sebagai proxy untuk mengukur tingkat kesulitan geografis suatu daerah, semakin sulit letak geografis suatu daerah maka semakin tinggi pula tingkat harga di daerah tersebut. Penghitungan dari Indeks Kemahalan Konstruksi (IKK) karenanya didasarkan atas suatu pendekatan tertentu dengan metode yang dikembangkan oleh BPS.

Selain variabel yang dipertimbangkan di atas, ada beberapa variabel penting lainnya yang belum diperhitungkan dalam pemodelan ANN ini. Menurut Setyawati (2002) dalam pemilihan variabel input berpengaruh secara signifikan terhadap keakuratan prediksi jaringan syaraf, seseorang dapat memperoleh hasil yang berbeda atau lebih baik jika variabel input penting lainnya sudah dipelajari. Variabel yang dapat diselidiki meliputi tinggi 
total bangunan, klasifikasi kualitas bahan struktural (beton dan baja), rasionya jumlah balok sekunder dengan jumlah total balok di lantai bangunan, jumlah balok dan kolom tiap lantai, dan lain-lain. Akan tetapi, ada batasan dalam penelitian ini, yaitu hanya variabel yang dapat dengan mudah diidentifikasi pada tahap perancangan desain awal yang dipertimbangkan untuk diteliti lebih lanjut.

Data biaya dan desain terkait dari 12 proyek Rumah Sakit Pratama dibagi menjadi dua set: satu set untuk melatih jaringan syaraf tiruan; dan set kedua untuk memvalidasi kinerja jaringan yang terlatih. Untuk setiap siklus pelatihan, sehingga satu set pelatihan yang berisi data untuk delapan proyek, dan satu set untuk validasi empat proyek. Tidak ada aturan umum yang mengatur dalam menentukan ukuran data pelatihan untuk pelatihan yang sesuai, tetapi sampel pelatihan harus mencakup semua spektrum data tersedia (Setyawati, 2002). Pada penelitian ini, data dari kasus ekstrim (yaitu, maksimum dan minimum) dipilih untuk tujuan pelatihan. Menurut Zhang dan Fuh (1998), set pelatihan dapat dimodifikasi jika performa model tidak memenuhi harapan pencapaian suatu nilai. Dengan menambahkan data baru ke sampel pelatihan dan melatih kembali jaringan yang sesuai dan memberikan hasil optimal.

Data pengujian umumnya dinormalisasi untuk kerahasiaan dan untuk efekifvitas model pelatihan ANN yang sedang dikembangkan. Normalisasi data pelatihan diakui dapat memperbaiki kinerja jaringan terlatih (Squiera, 1999). Dalam penelitian ini, nilai input dan output dinormalisasi untuk keperluan pelatihan dan pengujian. Sebuah neuron pada dasarnya menghitung jumlah input tertimbang mereka, mengurangi ambang batasnya dari jumlah tersebut, dan mentransfer hasil ini dengan sebuah fungsi. Hal ini dapat dijelaskan secara matematis berikut (Persamaan (1)):

$\boldsymbol{y} \boldsymbol{i}=\boldsymbol{f} \boldsymbol{i}\left(\sum_{\boldsymbol{j}=\mathbf{1}}^{n} \boldsymbol{w} \boldsymbol{i j} \boldsymbol{j} \boldsymbol{j}-\boldsymbol{s i}\right)($ Pers. 1)(Pers. 1)

Keterangan:

yi : output neuron

wij : bobot korespondensi

fi : fungsi transformasi $\begin{array}{ll}x j & \text { : input neuron } \\ \text { si } & \text { : nilai ambang neuron }\end{array}$

Neuron saling bergantung satu sama lain melalui bobot koneksi. Bobot ini memiliki pengaruh antara neuron. Semua neuron terhubung ke neuron lain di lapisan berikutnya. Fungsi aktivasi digunakan karena beberapa efek, jika diterapkan secara aditif, dapat menyebabkan nilai output turun di bawah garis bawah atau naik di atas batas atas. Arditi (2002), telah menjelaskan terkait kasus cross-impact analysis. Fungsi yang diadopsi untuk masalah estimasi biaya saat ini adalah hyperbolic tangent curve, yang didapat dari rumus (Persamaan (2)):

Activation Function $(x)(x)=\frac{e^{x}-e^{-x}}{e^{x}+e^{-x}}$ (Pers. 2)

Fungsi hyperbolic tangent curve ini menghasilkan nilai output antara) 1 dan 1 . Karakteristik fungsi aktivasi sangat penting karena dapat mendefinisikan perilaku model jaringan ANN.

\section{Tahap Pelatihan}

Permasalahan yang harus diselesaikan saat menerapkan jaringan syaraf tiruan ke masalah yang diteliti adalah menentukan prosedur pelatihan mana yang harus diadopsi dan diaplikasikan (Roxas, 2014).

Ada banyak alternatif prosedur lainnya untuk dipilih. Algoritma backpropagation merupakan metode yang cocok yang diaplikasikan dalam metode ini. Training adalah teknik pelatihan yang paling banyak digunakan untuk masalah yang serupa dengan penelitian saat ini (Hegazy,1998).

Algoritma backpropagation ini telah terbukti secara teoritis dan berkinerja baik dalam memodelkan fungsi nonlinier, serta mudah untuk dikodekan (Kesturi, 2012). Penambahan fungsi alogaritma untuk aturan aktivasi yang mengatur penyesuaian bobot di antara neuron, yaitu fungsi hyperbolic tangent yang digunakan dalam tahap pemodelan, pengaturan aturan dasar jaringan lainnya adalah terkait fungsi pembelajaran/ pelatihan.

Semua model pelatihan trial yang diuji coba dalam penelitian ini dilatih dalam mode yang dilandasi dengan algoritma pembelajaran 
backpropagation. Dengan demikian, bobot sambungan dimodifikasi terus menerus sampai terjadi kesalahan antara output yang diinginkan dan output model diminimalkan serta sebagai pemodel telah memutuskan ukuran set pelatihan dan jenis pelatihan, tingkat pembelajaran dan koefisien momentum, arsitektur jaringan ANN, dan jumlah iterasi untuk mencapai output model terbaik.

Algoritma backpropagation melibatkan pengurangan kesalahan secara bertahap antara output model dan output target (Rumelhart, 1986). Oleh karena itu, perlu pengembangan input ke pemetaan output dengan meminimalkan fungsi kesalahan biaya kuadrat rata-rata yang diukur dari serangkaian contoh tahap pelatihan. Nilai Mean Square Error dinyatakan sebagai berikut (Persamaan (3)):

$\boldsymbol{M S E}=\frac{\sqrt{\sum_{i=1}^{n}\left(\boldsymbol{x}_{i}-\boldsymbol{E}(\boldsymbol{i})\right)^{2}}}{n}($ Pers. 3)

Keterangan:

MSE : Mean Square Error

$n \quad$ : jumlah data tahap pelatihan

xi : parameter input

E(i) : target output

Mean Square Error adalah indikator ukuran secara keseluruhan untuk melihat hasil running dari pelatihan telah berhasil atau tidak (AlTabtabai, 1998). Pada tahapan ini mempunyai fungsi untuk mengevaluasi kinerja model selama proses pelatihan. Pada umumnya, tidak ada manfaat untuk melatih model ANN di luar titik di mana kinerjanya berhenti membaik pada saat rangkaian pengamatan uji. Suatu tahapan pelatihan dalam satu set proses pelatihan disebut epoch (Kusumadewi, 2004). Kesalahan error diukur untuk setiap running dari jumlah epoch yang dipilih dan hasilnya ditunjukkan sebagai kurva kinerja seperti yang ada pada Gambar 2, yang mana menunjukkan mean absolute error didapatkan $9.8057 \times 10^{-13}$. Pelatihan harus dihentikan saat mean square error tidak berubah selama periode tertentu sesuai dengan epoch target. Hal ini dilakukan untuk menghindari overtraining, dalam hal ini jaringan merekam nilai pelatihan dan tidak dapat membuat prediksi saat ada contoh yang tidak diketahui. Dalam kasus ini, nilai epoch batas digunakan 1000 kemudian ditemukan hasil yang cukup untuk proses pelatihan dalam rangkaian uji coba.

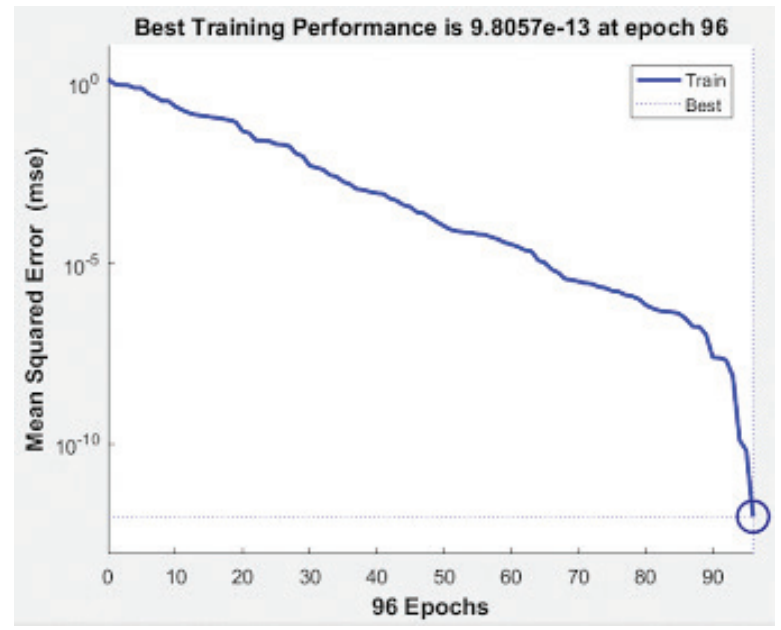

Gambar 2. Grafik Pelatihan Model ANN

Dua parameter pelatihan jaringan model ANN yang penting pada tahapan ini adalah tingkat pembelajaran dan koefisien momentum. Hasil konstan dari pelatihan ini ditentukan pada awal siklus pelatihan dengan menentukan kecepatan dan stabilitas jaringan itu sendiri (Kalogirou, 2001). Tingkat dari training menentukan jumlah modifikasi bobot di antara neuron selama setiap iterasi proses pelatihan (Al-Tabtabai, 2000). Salah satu cara yang memungkinkan pembelajaran lebih efektif tanpa proses osilasi adalah dengan menerapkan suatu koefisien momentum terhadap perubahan bobot yang digunakan dalam iterasi pelatihan pada model ANN sebelumnya (Erlianingsih, 2016). Dalam penelitian ini, diketahui bahwa koefisien 0.1 memiliki kinerja yang baik.

\section{Tahap pengujian}

Kinerja model ANN diukur dengan menggunakan rumus persentase error biaya (CPE) (Persamaan (4)):

$\boldsymbol{C P E}=\frac{E(i)-T(i)}{T(i)} \times \mathbf{1 0 0} \%$ (Pers. 4)

Keterangan:

T(i) : output nilai biaya aktual

E(i) : output nilai biaya hasil ANN

Efek yang dihasilkan dari masing-masing input jaringan terhadap output jaringan dapat 
dianalisis. Efek tersebut memberikan umpan balik mengenai parameter dari input mana yang paling signifikan. Untuk mencapai hal tersebut, analisis sensitivitas dilakukan. Analisis sensitivitas adalah sebuah metode untuk mengekstrak hubungan sebab dan akibat antara input dan output jaringan. Metode ini akan mengurangi ukuran jaringan dan kompleksitas model pada proses pelatihan. Selama analisis sensitivitas, fungsi pembelajaran jaringan dinonaktifkan, sehingga bobot jaringan tidak terpengaruh. Gagasan dasarnya adalah saat input ke jaringan diubah setiap saat dan terjadi perubahan yang sesuai kemudian hasil output dilaporkan sebagai persentase pada gambar. Dalam model ANN ini, pekerjaan beton dan pelat lantai serta jarak lokasi proyek dianggap sebagai parameter perancangan yang paling efektif. Selain itu, penggunaan pada dua variabel desain ini memiliki pengaruh akurasi prediksi rata-rata model $96.51 \%$.

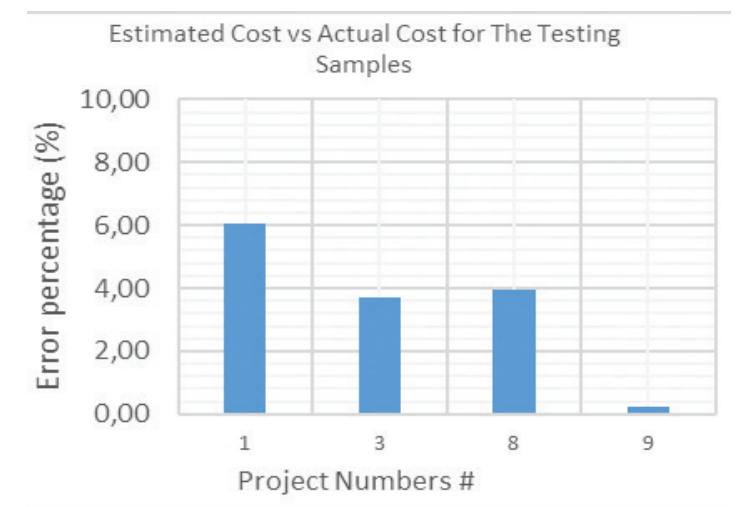

Gambar 3. Perbandingan Biaya Estimasi (ANN) dan Biaya Real pada Sampel Validasi

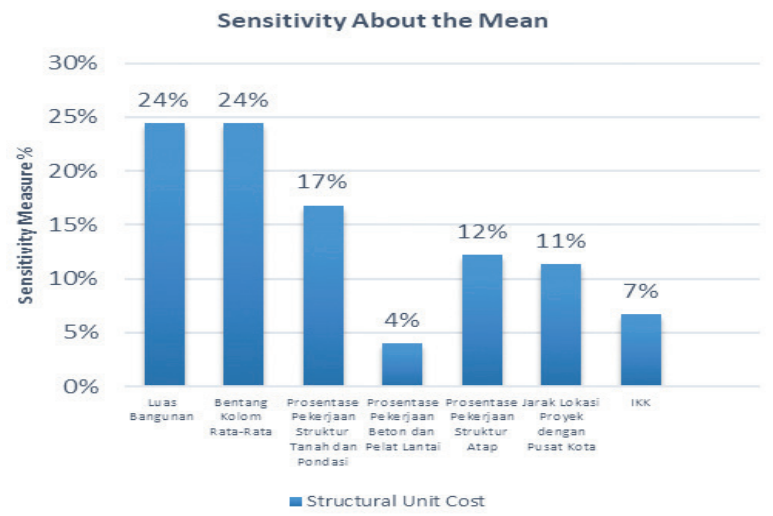

Gambar 4. Hasil Uji Sensitivitas Variabel terhadap Nilai Pekerjaan Struktural Berdasarkan Pengujian Korelasi Kendal-Tau \& Spearman
Tabel 2. Perbandingan Biaya Estimasi (ANN) dan Biaya Real pada Sampel Validasi

\begin{tabular}{l|lll}
\hline $\begin{array}{c}\text { Proyek } \\
\text { \# }\end{array}$ & $\begin{array}{c}\text { Harga Aktual } \\
\text { Nilai Pekerjaan } \\
\text { Struktur (Rp) }\end{array}$ & $\begin{array}{c}\text { Harga Estimasi } \\
\text { Nilai Pekerjaan } \\
\text { Struktur (Rp) }\end{array}$ & $\begin{array}{c}\text { Prosentase } \\
\text { Error (\%) }\end{array}$ \\
\hline$(1)$ & $(2)$ & $(3)$ & $(4)$ \\
1 & $5,914,517,910.14$ & $5,556,421,703$ & 6.05 \\
3 & $5,446,665,714.92$ & $5,647,907,212$ & 3.69 \\
8 & $2,680,877,891.70$ & $2,575,082,314$ & 3.95 \\
9 & $2,449,840,665.09$ & $2,456,088,718$ & 0.26 \\
\hline
\end{tabular}

Analisis korelasi perlu dilakukan untuk mengetahui erat atau tidaknya hubungan, arah hubungan dan berarti atau tidaknya hubungan antara variabel input independen dengan variabel output/dependen (Priyatno, 2013). Adapun analisis korelasi dilakukan terhadap 7 variabel input yang terdiri dari luas bangunan, bentang kolom rata-rata, prosentase pekerjaan struktur tanah dan pondasi, prosentase pekerjaan beton dan pelat lantai, pekerjaan prosentase struktur atap, IKK, dan jarak lokasi proyek. Korelasi dilakukan guna mengetahui ada atau tidaknya hubungan, kuat atau lemahnya hubungan dan arah hubungan antara variabel input tersebut terhadap variabel output yaitu harga kontrak. Karena data proyek sampel yang didapat merupakan data yang tidak terdistribusi normal setelah dilakukan uji normalisasi data, maka analisis korelasi yang digunakan adalah analisis korelasi dengan metode kendall-tau dan Spearman. Hasil yang diperoleh tersebut dapat dijelaskan pada Tabel 3.

\section{HASIL DAN PEMBAHASAN}

Data dari empat proyek Rumah Sakit Pratama digunakan untuk tujuan pengujian dan validasi. Hasil menunjukkan akurasi rata-rata 96.51\% (Gambar3 dan Tabel 2) dengan kesalahan kuadrat rata-rata MSE 9.8057 × $10^{-13}$. Angkaangka ini dianggap sebagai estimasi biaya yang baik di awal tahap desain perencanaan untuk menilai nilai suatu pekerjaan struktural. Hasil penelitian ini juga mengungguli studi Saner yang menghasilkan koefisien regresi linier hanya 0,47; sedangkan model saat ini tercapai 1 (Hasil dari model ANN). Penyimpangan maksimum kelebihan perkiraan biaya dari biaya sebenarnya 
sekitar $6.06 \%$ sedangkan deviasi rata-rata sekitar $3.49 \%$ (Tabel 2). Keakuratan perkiraan biaya dapat mendekati sistem pakar professional yang dikembangkan oleh Mohamed dan Celik, di mana perkiraan biaya total ditemukan antara kisaran $2 \%$ dan $4 \%$ dari biaya sebenarnya. Tentu saja, kita tidak boleh lupa bahwa perencana profesional menggunakan informasi yang lebih akurat dan lengkap tentang desain bangunan untuk pekerjaan struktural. Pada tahap perancangan desain awal bagi para perencana profesional, keakuratan model estimasi biaya yang digunakan untuk dasar dari perencanaan memiliki justifikasi yang tak ternilai untuk membuat keputusan yang lebih baik.

Tabel 3.Analisis Korelasi terhadap Harga Kontrak Pekerjaan Struktur

\begin{tabular}{|c|c|c|c|c|c|c|c|c|}
\hline \multirow[b]{2}{*}{ Variabel Input } & \multicolumn{4}{|c|}{ Nilai Kendals - Tau } & \multicolumn{4}{|c|}{ Nilai Spearman } \\
\hline & 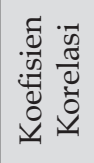 & Keterangan & 胥 & Keterangan & 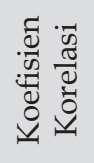 & Keterangan & 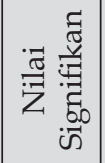 & Keterangan \\
\hline Luas Bangunan & 0.929 & \begin{tabular}{|l|}
$\begin{array}{l}\text { Hub. Kuat } \\
\text { (mendekati 1) }\end{array}$ \\
\end{tabular} & 0.001 & \begin{tabular}{|l} 
Ada Hubungan \\
(Kurang dari 0.01)
\end{tabular} & 0.976 & $\begin{array}{l}\begin{array}{l}\text { Hub. Kuat } \\
\text { (mendekati 1) }\end{array} \\
\end{array}$ & 0 & \begin{tabular}{|l|}
$\begin{array}{l}\text { Ada Hubungan } \\
\text { (Kurang dari 0.01) }\end{array}$ \\
\end{tabular} \\
\hline $\begin{array}{l}\text { Bentang Kolom } \\
\text { Rata-Rata }\end{array}$ & 0.929 & \begin{tabular}{|l|}
$\begin{array}{l}\text { Hub. Kuat } \\
\text { (mendekati 1) }\end{array}$ \\
\end{tabular} & 0.001 & \begin{tabular}{|l|} 
Ada Hubungan \\
(Kurang dari 0.01)
\end{tabular} & 0.976 & \begin{tabular}{|l}
$\begin{array}{l}\text { Hub. Kuat } \\
\text { (mendekati 1) }\end{array}$ \\
\end{tabular} & 0 & \begin{tabular}{|l|} 
Ada Hubungan \\
(Kurang dari 0.01)
\end{tabular} \\
\hline $\begin{array}{l}\text { Prosentase } \\
\text { Pekerjaan } \\
\text { Struktur Tanah } \\
\text { dan Pondasi } \\
\end{array}$ & 0.571 & $\begin{array}{l}\text { Hub. Kuat } \\
\text { (mendekati 1) }\end{array}$ & 0.48 & $\begin{array}{l}\text { Tidak Ada } \\
\text { Hubungan (lebih } \\
\text { dari 0.05) }\end{array}$ & 0.738 & $\begin{array}{l}\text { Hub. Kuat } \\
\text { (mendekati 1) }\end{array}$ & 0.37 & $\begin{array}{l}\text { Tidak Ada Hubungan } \\
\text { (lebih dari 0.05) }\end{array}$ \\
\hline $\begin{array}{l}\text { Prosentase } \\
\text { Pekerjaan Beton } \\
\text { dan Pelat Lantai } \\
\end{array}$ & 0.143 & $\begin{array}{l}\text { Hub.Lemah } \\
\text { (mendekati 0) }\end{array}$ & 0.621 & $\begin{array}{l}\text { Tidak Ada } \\
\text { Hubungan (lebih } \\
\text { dari 0.05) }\end{array}$ & 0.167 & $\begin{array}{l}\text { Hub.Lemah } \\
\text { (mendekati 0) }\end{array}$ & 0.693 & $\begin{array}{l}\text { Tidak Ada Hubungan } \\
\text { (lebih dari 0.05) }\end{array}$ \\
\hline $\begin{array}{l}\text { Prosentase } \\
\text { Pekerjaan } \\
\text { Struktur Atap } \\
\end{array}$ & 0.357 & $\begin{array}{l}\text { Hub.Lemah } \\
\text { (mendekati 0) }\end{array}$ & 0.316 & \begin{tabular}{|l|} 
Tidak Ada \\
Hubungan (lebih \\
dari 0.05) \\
\end{tabular} & 0.595 & $\begin{array}{l}\text { Hub. Kuat } \\
\text { (mendekati 1) }\end{array}$ & 0.12 & $\begin{array}{l}\text { Tidak Ada Hubungan } \\
\text { (lebih dari 0.05) }\end{array}$ \\
\hline IKK & 0.357 & $\begin{array}{l}\text { Hub.Lemah } \\
\text { (mendekati 0) }\end{array}$ & 0.316 & \begin{tabular}{|l|} 
Tidak Ada \\
Hubungan (lebih \\
dari 0.05) \\
\end{tabular} & 0.524 & $\begin{array}{l}\text { Hub. Kuat } \\
\text { (mendekati 1) }\end{array}$ & 0.183 & $\begin{array}{l}\text { Tidak Ada Hubungan } \\
\text { (lebih dari 0.05) }\end{array}$ \\
\hline $\begin{array}{l}\text { Jarak Lokasi } \\
\text { Proyek dengan } \\
\text { Pusat Kota } \\
\end{array}$ & 0.214 & $\begin{array}{l}\text { Hub.Lemah } \\
\text { (mendekati 0) }\end{array}$ & 0.458 & $\begin{array}{l}\text { Tidak Ada } \\
\text { Hubungan (lebih } \\
\text { dari 0.05) } \\
\end{array}$ & 0.31 & $\begin{array}{l}\text { Hub.Lemah } \\
\text { (mendekati 0) }\end{array}$ & 0.456 & $\begin{array}{l}\text { Tidak Ada Hubungan } \\
\text { (lebih dari 0.05) }\end{array}$ \\
\hline
\end{tabular}

*. Correlation is significant at the 0.05 level (2-tailed).

**. Correlation is significant at the 0.01 level (2-tailed)

\section{SIMPULAN}

Berdasarkan hasil analisis korelasi KendallTau dan Spearman yang telah dilakukan, dapat diidentifikasi faktor-faktor yang berpengaruh signifikan terhadap biaya pekerjaan struktural pembangunan konstruksi gedung Rumah Sakit Pratama (2015) antara lain: (a) Luas bangunan, (b) Bentang kolom rata-rata, dan (c) Prosentase pekerjaan struktur tanah dan pondasi

Nilai IKK (Indeks Kemahalan Konstruksi) dan Jarak Lokasi Proyek dari pusat ibukota provinsi tidak memiliki nilai pengaruh sensitivitas yang tinggi terhadap besarnya nilai kontrak konstruksi Rumah Sakit Pratama (2015). Dari rumus empiris yang diperoleh dari metode ANN didapatkan prosentase error/
MMRE maksimal yang dihasilkan adalah sebesar $0.139 \%$.

Dari hasil penelitian juga dapat diketahui bahwa nilai prosentase komponen pekerjaan Gedung Negara untuk bangunan RS Pratama memiliki nilai prosentase yang berbeda dengan nilai yang diacu pada Permen PU No.45/PRT/M/2007 tentang Pedoman Teknis Pembangunan Bangunan Gedung Negara, perbandingan dapat dilihat pada tabel 4. Oleh karena itu, dapat dikatakan bahwa nilai yang ditetapkan oleh Permen PU belum cukup mengakomodir untuk penggunan prosentase perbandingan komponen pekerjaan Gedung Negara terutama untuk bangunan Rumah Sakit Pratama, sehingga diharapkan data 
Permen PU dapat dikaji ulang agar dapat lebih kompeten dan dapat digunakan untuk acuan ke depannya. Terkait Permen PU itu sendiri sudah cukup lama belum dilakukan revisi dan tentunya kurang cukup kompeten bila digunakan untuk perkembangan konstruksi pada masa sekarang.

Tabel 4. Perbandingan Prosentase Komponen Pekerjaan Berdasarkan Permen PU No.45/PRT/M/2007

\begin{tabular}{llll}
\hline \multicolumn{1}{c}{ NO. } & \multicolumn{3}{c}{ PROSENTASE PEKERJAAN (\%) } \\
PROYEK & Pondasi & Struktur & Atap \\
\hline $\mathbf{2}$ & 3.76 & 46.69 & 15.25 \\
$\mathbf{4}$ & 2.82 & 34.65 & 14.84 \\
$\mathbf{5}$ & 1.96 & 32.10 & 12.82 \\
$\mathbf{6}$ & 2.03 & 33.05 & 11.28 \\
$\mathbf{7}$ & 1.52 & 33.27 & 12.47 \\
$\mathbf{1 0}$ & 3.05 & 35.80 & 16.04 \\
$\mathbf{1 1}$ & 3.29 & 35.12 & 15.20 \\
$\mathbf{1 2}$ & 6.03 & 39.07 & 16.10 \\
Rerata & 3.06 & 36.22 & 14.25 \\
\hline Range & $5-10 \%$ & $25-35 \%$ & $8-10 \%$ \\
Permen PU &
\end{tabular}

Metode Artificial Neural Network (ANN) mempelajari penyelesaian masalah dari contoh, sehingga kinerja model jaringan syaraf tiruan untuk estimasi biaya sangat bergantung pada kualitas dan kuantitasnya contoh inputnya pada proses training, semakin banyak contoh yang ada, kemungkinan semakin sedikit prediksi error yang dihasilkan dari model ANN. Dengan demikian, untuk mempelajari metode pemodelan dan prediksi, dan membuat model ANN untuk prediksi biaya pekerjaan struktural yang akurat, perlu kebutuhan untuk keandalan, kualitas tinggi, data biaya pekerjaan struktural skala penuh dari berbagai jenis dan kondisi.

Meskipun data yang dipilih untuk model ANN pada penelitian ini terbatas cakupannya, hasilnya dapat mendorong penelitian lebih lanjut terhadap kumpulan data yang diperluas ke depannya. Tujuan utama dari penelitian ini adalah untuk memperkenalkan pendekatan baru dan alternatif untuk menggunakan jaringan syaraf tiruan untuk estimasi biaya nilai pekerjaan struktur bangunan pada tahap awal proses perancangan bangunan Rumah Sakit Pratama. Pendekatan ini terbukti mampu memberikan perkiraan biaya pekerjaan struktur yang akurat dengan menggunakan tujuh parameter yang tersedia di awal tahap perencanaan. Model ANN ini menetapkan metodologi yang dapat memberikan cara estimasi biaya pekerjaan struktur yang ekonomis untuk Rumah Sakit Pratama pada proses desain bangunan di masa akan datang.

Kelemahan utama dari metode perkiraan biaya konvensional adalah kebutuhan akan informasi proyek yang terperinci, selain itu ketidakpastian mengenai pengembangan proyek dan perubahan beberapa parameter desain, dan lain-lainnya. Hasil permodelan ANN kami telah dikembangkan untuk estimasi biaya awal dari nilai pekerjaan struktural pada bangunan Rumah Sakit Pratama dengan menerapkan prinsip-prinsip pembelajaran neural network yang sudah mengalami proses pelatihan dan validasi. Model ANN ini membuktikan bahwa jaringan syaraf tiruan mampu mengurangi ketidakpastian terkait dengan biaya suatu item pekerjaan struktural bangunan Rumah Sakit Pratama.

Kemampuan permodelan ANN untuk estimasi biaya merupakan hal inovatif dan perlu dikembangkan. Pendekatan metode ini memperluas kemungkinan membangun model berbasis pengetahuan skala penuh untuk memprediksi biaya pekerjaan struktural Rumah Sakit Pratama. Pendekatan ini dapat memecahkan pemetaan non-linear yang kompleks untuk memprediksi total biaya setiap paket pekerjaan pada tahap proses perancangan dan konstruksi. ANN juga dapat dimanfaatkan di bidang manajemen proyek lainnya seperti mencari besaran dari nilai kualitas, produktivitas, konstrukabilitas, prediksi rekayasa nilai, penjadwalan, dan lainlainnya.

\section{DAFTAR PUSTAKA}

Al-Tabtabai H, Alex AP. Modeling The Cost Of Political Risk In International Construction Projects. Project Manage J2000;31(3):4-13. 
Anitianata, T., 2014. Analisis Prediksi Nilai Kondisi Bangunan Atas Jembatan Dengan Metode Neural Network ( Studi Kasus: Beberapa Jembatan Dengan Bangunan Atas Beton di Jawa Tengah). Yogyakarta: Tesis. Universitas Gadjah Mada.

Aptiyasa, P.A.A..,2014. CostModel Konseptual Untuk Bangunan Gedung Rumah Sakit, Yogyakarta: Tesis. Universitas Atmajaya.

Arditi D. Cross-Impact Analysis Of Information Technologies And Project Management Knowledge Areas In The Building Design Process. Pennsylvania: PMI; 2002 [p. 435-54, Chapter 26].

Badan Pusat Statistik., 2015. Indeks Kemahalan Konstruksi 2015. Jakarta: CV.Dharmaputra.

Badan Pusat Statistik., 2015. Statistik 70 Tahun Indonesia Merdeka. Jakarta: CV.Dharmaputra.

Creese RC, Li L. Cost Estimation Of Timber Bridges Using Neural Networks. Cost Eng 1995;37(5):17-22.

Erlianingsih, H., 2016. Prakiraan Harga Gedung Kampus dengan Menggunakan Pemodelan ANN (Studi Kasus: Gedung Universitas Gadjah Mada). Yogyakarta:Tesis. Universitas Gadjah Mada.

Febriani, L., 2016. Prediksi Dimensi Optimum Struktur Portal Baja (Gable Frame) Dengan Menggunakan Metode Artificial Neural Network (ANN). Yogyakarta: Tesis. Universitas Gadjah Mada.

Firdausa, F., 2015. Optimasi Dimensi Profil Batang Bangunan Atas Jembatan Rangka Baja Tipe Warren Tertutup Dengan Metode Artificial Neural Network. Yogyakarta: Tesis. Universitas Gadjah Mada.

Hegazy, T. and A. Ayed., 1998. A Neural Network Model for Parametric Cost Estimation of Highway Projects.
Journal of Construction Engineering and Management, ASCE, Vol. 24 No.3,210-218.

Kalogirou SA. Artificial Neural Networks In Renewable Energy Systems Applications: A Review. Renew Sust Energ Rev 2001;5:37

Kementerian Pekerjaan Umum., 2007. Peraturan Menteri Pekerjaan Umum No. 45/PRT/M/2007 tentang Pedoman Teknis Pembangunan Bangunan Gedung Negara. Jakarta

Kesturi, L., 2012. Estimasi Biaya Tahap Konseptual pada Konstruksi Gedung Perkantoran dengan Metode Artificial Neural Network. Jakarta: Tesis. Universitas Indonesia.

Kim, G.H, Sung, H.A., Kyung I.K., 2004. Comparison of construction cost estimating models based on regression analysis, neural networks, and casebased reasoning. Elsevier.

Kusumadewi, S., 2004, Membangun Jaringan Saraf Tiruan Menggunakan MATLAB \& Excel Link. Yogyakarta: Penerbit Graha Ilmu.

Mohamed A, Celik T. Knowledge Based-System For Alternative Design, Cost Estimating And Scheduling. Knowl Based Syst 2002;15:177-88.

Priyatno, D., 2013. Analisis Korelasi, Regresi dan Multivariate dengan SPSS. Yogyakarta: Gava Media.

Rahmadi, N. H., 2014. Prediksi Nilai Rating Factor Jembatan Komposit Baja-Beton Dengan Menggunakan Artificial Neural Network. Yogyakarta: Tesis. Universitas Gadjah Mada.

Rumelhart D., Hinton G. and Williams R., 1986. Learning Internal Representations by Error Propagation. U.S.A: Cambridge: MIT Press.

S.Zeynep. Dogan, 2004. A Neural Network Approach for Early Cost Estimation of Structural System of Buildings www. elsevier.com/locate/ijproman 
Safitri, R. A., 2015. Optimasi Pradesain Dimensi Gelagar Jembatan Komposit Baja-Beton Dengan Menggunakan Pemodelan ANN (Artificial Neural Network). Yogyakarta: Tesis. Universitas Gadjah Mada.

Saner C., 1993. A Proposal For Cost-Estimation For Structural Systems Of 4-8 Storey Residential Buildings. MSc Thesis, Istanbul Technical University

Sebastian, N. P., 2016. Prediksi Dimensi Optimum Struktur Atap Rangka Baja Canai Dengan Metode Artificial Neural Network. Yogyakarta: Tesis. Universitas Gadjah Mada.

Setyawati, Dkk, 2002. Neural Network for Cost Estimation. AACE InternationalTransaction,ES131.

Shtub A, Versano R. Estimating The Cost OfSteel Pipe Bending, A Comparison Between Neural Networks Andregression Analysis. Prod Econ 1999;62:201-7.

Shottlander, E.D., 2006. How Accurate are Your Estimates? AACE International Transactions.

Siang, J.J., 2009. Jaringan Syaraf Tiruan dan Pemogramannya Menggunakan MATLAB. Yogyakarta: Penerbit ANDI.

Sodikov, J., 2005. Cost Estimation of Highway Projects in Developing Countries: Artificial Neural Network Approach. Journal of the Eastern Asia Society for Transportation Studies, Vol. 6, 1036-1047.
Squeira I., 1999. Neural Network-Based Cost Estimating,Master's Thesis. Department of Building, Civil and Environmental Engineering, Concordia University

Suryani, E., 2015. Optimasi Dimensi Balok Beton Prategang Profil I Untuk Jembatan Kelas A Dengan Menggunakan Pemodelan ANN (Artificial Neural Network). Yogyakarta: Tesis. Universitas Gadjah Mada.

Syamsi, M. I., 2015. Prediksi Rating Factor Jembatan Beton Prategang Tipe-I Dengan Metode Artificial Neural Network. Yogyakarta: Tesis. Universitas Gadjah Mada.

Wartati, D., Nur A.E., 2016. Aplikasi Jaringan Saraf Tiruan dan Particle Swarm Optimization untuk Peramalan Indeks Harga Saham Bursa Efek Indonesia. Jurnal Teknosains UGM Vol.6, ISSN: 2089-6131 (Print), ISSN: 2443-1311 (Online)

Wijiyanto, N.A, Kusrini D.E., Irhamah, 2012. Peramalan Nilai Kontrak Konstruksi $\mathrm{PT}^{\prime} \mathrm{X}^{\prime}$ dengan Menggunakan Pendekatan Regeresi Time Series dan ANFIS. Jurnal Sains dan Seni ITS Vol.1,ISSN:2301-928X.

Yudhistira, A. T., 2014. Prediksi Penurunan Kapasitas Struktur Atas Jembatan Rangka Baja Dengan Metode Artificial Neural Network. Yogyakarta: Tesis. Universitas Gadjah Mada.

Zhang YF, Fuh JYH, 1998. A Neural Network Approach For Early Cost Estimation Of Packaging Products. Comput Ind Eng 1998;34(2):433-50. 